\title{
Photovoice for mobilizing insights on human well-being in complex social- ecological systems: case studies from Kenya and South Africa
}

\author{
Vanessa A. Masterson $^{1}$, Shauna L. Mahajan ${ }^{1,2}$ and Maria Tengö $^{1}$
}

\begin{abstract}
The value of diverse perspectives in social-ecological systems research and transdisciplinarity is well recognized. Human well-being and how it is derived from dynamic ecosystems is one area where local knowledge and perspectives are critical for designing interventions for sustainable pathways out of poverty. However, to realize the potential to enrich the understanding of complex dynamics for sustainability, there is a need for methods that engage holistic ways of perceiving human-nature interactions from multiple worldviews that also acknowledge inequalities between scientific and other forms of knowledge. To date, photovoice has been used to elicit local knowledge and perspectives about ecosystem changes and ecosystem services. We expand this to explore the utility of the method for facilitating the mobilization of plural insights on human well-being, which is subject to complex social-ecological dynamics, and its role in processes for coproduction of knowledge that acknowledges the need for equity and usefulness for all actors. Drawing on two cases, one in community-based marine protected areas in Kenya and one dealing with agricultural decline and rural-urban migration in South Africa, we demonstrate two modes of application of photovoice: as a scoping exercise and as a deep learning tool. The studies descriptively illustrate how photovoice can depict the hidden and often neglected intangible connections to ecosystems, plural and disaggregated perceptions of complex social-ecological dynamics, and issues of access and distribution of ecosystem benefits. The studies also show how photovoice can encourage equitable participation of nonacademic actors in research processes and in particular contribute to mobilization of knowledge and translation of knowledge across knowledge systems. We discuss how local perspectives may be further recognized and incorporated in transdisciplinary research and reflect on the practical and ethical challenges posed by using photographs in participatory research on social-ecological systems.
\end{abstract}

Key Words: coproduction of knowledge; human well-being; Kenya; participation; poverty alleviation; social-ecological system; South Africa; transdisciplinary research

\section{INTRODUCTION}

Many communities that depend on natural resources for their well-being are increasingly impacted by drivers of social and ecological change, often originating at regional or global scales (Aggarwal 2006, Adger et al. 2009, Biggs et al. 2011). Although many communities are vulnerable to such changes, they and the knowledge they hold are often excluded from debates or passive in the depiction of ecological changes and the impacts on their own well-being (Mistry and Berardi 2016). Including local communities in generating knowledge on social-ecological change can foster a deeper understanding of complex humannature relationships, the influence of this complexity on human well-being, and how these interactions translate into vulnerabilities or opportunities for sustainable pathways out of poverty (Berbés-Blázquez 2012, Brondizio and Le Tourneau 2016, Tengö et al. 2017). To do this, tools and methods are needed that can capture both the perspectives and experiences of local and marginalized groups, as well as their knowledge and understanding of well-being and social-ecological dynamics (Mistry and Berardi 2016, Tengö et al. 2017). We engage with photovoice as such a method and probe and discuss its potential to contribute to including local perspectives and knowledge in social-ecological systems research.

A holistic approach to human well-being can be defined as a state of being with others, where human needs are met, where one can act meaningfully to pursue one's goals, and where one enjoys a satisfactory quality of life (McGregor 2007). Our focus is on the aspects of human well-being that are supported by ecosystems, highlighting the linkages between quality of life and functioning ecosystems at the intersection of social and ecological systems (Millennium Ecosystem Assessment 2005, Folke et al. 2016). In the last 10 years, there has been an increase in research linking ecosystem services to human well-being, calling attention to the many ways in which ecosystems support well-being (for overview see Summers et al. 2012, Yang et al. 2013, and Cruz-Garcia et al. 2017). Despite this attention, there are still a number of gaps in our understanding of how ecosystem dynamics precisely affect human well-being and livelihoods (Balmford and Bond 2005, Carpenter et al. 2009).

First, there has been a strong focus on direct and tangible impact benefits of ecosystems for well-being, and neglect of nonmaterial benefits such as cultural ecosystem services that are difficult to measure (Daniel et al. 2012, Chan et al. 2012, Cruz-Garcia et al. 2017). There is a need to engage with a range of understandings and culturally embedded perspectives of what constitutes wellbeing (Berbés-Blázquez 2012, Cocks et al. 2016). Second, there is a lack of understanding of how ecosystems impact different types and groups of people (Daw et al. 2011, Cruz-Garcia et al. 2017) and the importance of considering equity issues in managing ecosystems (Pascual et al. 2014). It has been long recognized that communities at the forefront of environmental change are rarely homogenous entities with shared norms and values; rather they comprise actors with varied perspectives and levels of power (Agrawal and Gibson 1999, Hulme and Murphree 2001). Under conditions of increasingly rapid social and ecological change, there is a strong need to capture the heterogeneity and pluralism of perspectives within communities (Cook 2015) in order to capture the range of feedbacks and how they impact on well-being 
across different groups. Furthermore, there is also a need to capture differential access to ecosystem services by marginalized groups (Berbés-Blázquez 2012). A last gap identified is that there is still very little empirical research investigating the links between ecosystem services and well-being in Africa, Asia, and Latin America (Cruz-Garcia et al. 2017).

To counter top-down approaches to solutions for poverty alleviation that may malign marginal groups and alternative knowledge systems and the insights they may provide (Maclean and Cullen 2009, Tengö et al. 2014, Cook 2015), there have been calls for participatory methods that can engage groups who have historically been marginalized in management processes (Bosak 2008, Castleden et al. 2009, Maclean and Cullen 2009) as well as incorporate community knowledge, preferences, and values into decision making (Lynam et al. 2007). However, building relationships for what is increasingly referred to as coproduction of knowledge, e.g., involving civil society and decision makers in the research process, to strengthen legitimacy and usefulness of knowledge for addressing critical issues (Cash et al. 2003, Clark et al. 2016), can be challenging. It is particularly difficult in a context of power inequalities and when actors have different cultural frames of reference, not the least in a developing world context (Tengö et al. 2014, Steelman et al. 2015). Such challenges are related both to differences in ways of knowing and understanding the world, as well as to securing equitable, representative, and efficient participation of diverse actors in processes for coproduction of knowledge (Tengö et al. 2017). Tengö et al. (2017) suggest five tasks to guide knowledge partnerships with inherent power asymmetries: the need to mobilize knowledge that is tacit or in forms that are not easily shared, to translate knowledge between different actors, to negotiate convergence and divergence, to synthesize in ways that do not mask diversity, and to make sure that knowledge is applied in the full range of relevant contexts.

We make a case for using photovoice as a participatory research method for understanding complex social-ecological connections: specifically, how individuals and groups experience ecosystem change in relation to their well-being. Photovoice is a method that facilitates the expression of opinions, knowledge, and experiences by participants through taking photographs and group discussion and learning. We argue that photovoice can be particularly relevant for mobilizing knowledge that is tacit or context specific and provide boundary objects that can improve translation of understanding between researchers and communities (cf. Tengö et al. 2017). We present a brief background and clarification of photovoice, and expand on previous use of photovoice in environmental sciences, to explore the utility of this method to understand perceptions of human well-being related to ecosystem dynamics. We draw on two case studies to explore systems in transition in sub-Saharan Africa, facing varied drivers of global change: in Kenya, the perceptions of community-based marine protected areas and their impacts on human well-being; and in South Africa, declining agriculture in the face of continued urban migration. In both studies, photovoice was used as a part of a larger toolbox of methods to understand connections to nature and perceptions of well-being. The two cases also showcase the varied ways in which photovoice can be applied: through a scoping approach and through long engagement.
Building on initial work using photovoice (and photo elicitation) in a social-ecological system (SES) context (e.g., Berbés-Blázquez 2012, Beh et al. 2013, Bennett and Dearden 2013) we use the cases to illustrate that photovoice can be applied in SES research in particular to (1) build a deeper and disaggregated understanding on social-ecological dynamics and human well-being, and (2) enable coproduction of knowledge that honors diverse knowledge systems, perspectives, and worldviews. We conclude with a discussion on the modes of implementation of photovoice in research, the potential contribution of photovoice in broader transdisciplinary processes, and also explore the limitations and ethical considerations of photovoice as a tool in social-ecological research.

\section{BACKGROUND}

Participatory photography has been shown to be effective in engaging stakeholders in multiple research and development arenas, for example, in public health research (Wang and Burris 1997), leisure and sense of place research (Stedman et al. 2004, 2014), and in social advocacy work by NGOs such as PhotoVoice (Blackman 2007). Photovoice as a method builds on a long legacy of photography as a research medium in, e.g., anthropology and the social sciences (Harper 2002, 2003, Pink 2003). For example, the commonly used photo elicitation was first documented by Collier (1957) whose study used photographs to aid an interview and elicit more comprehensive discussions than semistructured interviews. The evocative nature of photographs serves as an effective stimulant for conversation among researchers and participants while allowing time for reflection about the issues (Harper 2002, Stedman et al. 2004, Briggs et al. 2014). In the spirit of other manifestations of this method such as recreation studies' visitor employed photography (Cherem and Driver 1983), photo elicitation has evolved to become a method through which interviewees themselves take photos and explain their photographs through one-on-one interviews (Harper 2002, Beilin 2005, Briggs et al. 2014, Stedman et al. 2014). Typically, collected visual data is used to stimulate rich discussions and are secondary to the narratives and conversational data gained through the interviews.

Photovoice as a method, however, has a stronger emphasis on participation, group discussion of photographs, and the use of photographs to convey a message. Participants take photographs of their everyday realities and come together as a group to identify, discuss, and represent community issues through photographs and critical discussion and reflection (Wang and Burris 1997, Wang et al. 1998). First applied in a public health needs assessment with rural women in the Chinese province of Yunnan (Wang and Burris 1997, Wang et al. 1998), photovoice continues to be widely applied in health research and in a myriad of different settings (see Hergenrather et al. 2009 for a review). Photovoice takes its inspiration from Freire's approach for critical education, as participants use photographs to reflect upon their own realities and to act to promote change (Wang and Burris 1994). Photovoice also has roots in feminist theory and addresses power biases of participatory research by giving more control of the research process to participants (Wang and Burris 1997). And last, photovoice draws from documentary photography to portray socially relevant phenomena, deemed important by the participants. These inspirations come together to highlight diverse local perspectives, elevate often marginalized voices to policy 
contexts, and link research to action in public health (Kramer et al. 2010, Catalani and Minkler 2010) and in the nonprofit and development sector, e.g., PhotoVoice (https://photovoice.org/ $)^{[1]}$.

Photovoice took different forms: some with an explicit group component, where participants came together to discuss and learn (Baldwin and Chandler 2010, Beh et al. 2013, Kong et al. 2015) and others where group discussion was less emphasized (BerbésBlázquez 2012, Bennett and Dearden 2013). In these studies there was also variation in the amount of space provided for participants to express their own concerns, an aspect taken up in cultural geography photovoice usage (Bosak 2008, Castleden et al. 2008, Maclean and Cullen 2009, Maclean and Woodward 2013).

In sustainability science, photo elicitation has been employed to understand complex relationships to landscapes (Beilin 2005), sense of place (Stedman et al. 2004, 2014, Briggs et al. 2014), and to elicit local knowledge about management of landscapes (Sherren et al. 2012, Kong et al. 2015). Photovoice has similarly been used to explore ecosystem services with communities (Berbés-Blázquez 2012), elicit local ecological knowledge about conservation and human-wildlife conflict options (Beh et al. 2013), and evaluate environmental quality and land management actions (Kong et al. 2015). There have also been innovative uses of photovoice to understand the perceptions of environmental changes (Baldwin and Chandler 2010) and how people respond to and interact with ecosystem dynamics (Bennett and Dearden 2013), through understanding community perceptions of change and risk that have significant implications for a community's willingness and ability to adapt to changes. Despite BerbesBlasquez's (2012) call, there has been limited use of photovoice to explore the distribution of ecosystem benefits and disaggregated experiences of ecosystem-linked well-being.

In our use of the term "photovoice" for studying social-ecological systems, we borrow elements from the approaches discussed above. We conceptualize photovoice as a research process of facilitating participants' exploration of an issue through taking their own photographs. Participants take photographs of their own landscapes, and their daily lives and concerns. Then, in the spirit of photo elicitation, representative photographs are used to stimulate discussion and reflection on their personal and collective interactions with the natural world (Beilin 2005). Along with the model of photovoice (Wang and Burris 1997), photographs are discussed in focus groups to encourage learning, trust, and reflexivity among the participants. We also draw inspiration from the use of photovoice to facilitate active participation in generating knowledge on the lives and environments of participants (Wang and Burris 1997, Beilin 2005, Maclean and Woodward 2013).

\section{CASE STUDIES}

We present the two case studies carried out in impoverished communities with strong connections to ecosystem dynamics in Kenya and South Africa. In each study, the directive for photovoice exercises was broadly framed around the concept of human well-being as derived from ecosystems. Photovoice was used in both studies as one tool in a suite of research methods including semistructured interviews and focus groups to understand perceptions of human-nature interactions and facilitate effective participation. We elaborate on the use of photovoice in the context of vulnerable communities and socialecological systems in transition, and discuss the utility of photovoice in other social-ecological systems research contexts.

The two cases also represent two distinct modes in which photovoice can be applied in social-ecological research contexts, summarized in Table 1. The Kenya case employed photovoice in a rapid assessment (a scoping tool) that helped obtain a broader picture of a social-ecological system in a limited amount of time. In the South Africa case, photovoice was used to gain in-depth understanding through continued engagement and collaboration with fewer participants over a longer period of time.

\section{Community-based conservation and human well-being in coastal Kenya}

Because of conflict and noncompliance associated with centralized, top-down management of fisheries in the coast province of Kenya, there has been a shift to management strategies that embrace elements of both community-based conservation and comanagement (Cinner et al. 2012). As part of this transition over the last decade, a number of community-based marine protected areas (called tengefus) have formed that have been largely initiated and managed by communities themselves, with support from NGOs, local and international conservation and development donors, and the government. Because these initiatives are relatively new, the research carried out in 2013 aimed to explore the social dynamics surrounding these initiatives in two sites, including the first-ever tengefu in Kenya, and a nearby site where this tengefu was implemented several years later. The study explored individual perceptions of each tengefu, and impacts on ecosystem services and human well-being.

Photovoice was employed as an initial method to gain an understanding of the range and perceptions of ecosystem services provided by the tengefus and its impact on well-being (Table 1). Thirty-six research participants across two sites were selected to participate in the study based on (1) willingness and interest in partaking in the study and (2) belonging to one of three resource user groups identified by prior research: spear gun fishers, gill net fishers, or fish traders. Participants were identified by snowball sampling with the help of a local NGO, and were a majority of male fishers, one male fish trader, and several female fish traders.

Before beginning the research process, the study was explained (verbally and written), and participants signed an informed consent form to participate in the study and the photovoice exercise. Participants were then given a 27 -exposure disposable camera. An introductory session covered basic camera care, and how to take a photo. The prompts given to photographers were the following: "Can you photograph what in nature/the marine ecosystem contributes to your wellbeing?" and "Can you show through your photographs how/if your wellbeing has changed as a result of the implementation of the tengefu?"

Because the exercise was a new process for participants, the facilitators showed a few examples from both the local context and from a different context to illustrate what was meant by nature and connections between nature and well-being. Only a few examples were shown to avoid the examples influencing photographer behavior. Participants kept the cameras for three to seven days, after which cameras were picked up and sent for processing. After approximately one week when photographs had 
Table 1. Comparison of application of photovoice method in two case studies. More information can be found in Mahajan and Daw (2016), Masterson (2016), and Masterson et al. (2017).

\begin{tabular}{|c|c|c|}
\hline & Scoping tool: Kenya case study & In-depth exploration: South Africa case study \\
\hline $\begin{array}{l}\text { Social-ecological system problem under } \\
\text { investigation }\end{array}$ & $\begin{array}{l}\text { The social dynamics surrounding newly } \\
\text { implemented community-based marine } \\
\text { protected areas (tengefus) in the context of } \\
\text { ecosystem degradation and poverty alleviation }\end{array}$ & $\begin{array}{l}\text { Decline of farming and natural resource use in village } \\
\text { landscape of communal tenure, the context of urban labor } \\
\text { migration }\end{array}$ \\
\hline $\begin{array}{l}\text { Conceptual tools to investigate social- } \\
\text { ecological linkages }\end{array}$ & $\begin{array}{l}\text { Perceptions of ecosystem services and human } \\
\text { well-being }\end{array}$ & Sense of place as an emergent social-ecological connection \\
\hline $\begin{array}{l}\text { Number of photographic exercises and } \\
\text { feedback session }\end{array}$ & $\begin{array}{l}\text { Single over six weeks } \\
\text { Single photographic feedback session with } \\
\text { follow-up discussions over six weeks }\end{array}$ & Between four and six sessions over five weeks \\
\hline $\begin{array}{l}\text { Total number of participants and } \\
\text { groups }\end{array}$ & 36 (9 groups) & 19 (4 groups) \\
\hline Length of photographing exercises & Participants had cameras for three to five days & Participants had cameras for one to two hours or overnight \\
\hline Cameras used & Single-use cameras & Simple and small digital cameras \\
\hline Themes of directives to participants & $\begin{array}{l}\text { How does the marine ecosystem influence well- } \\
\text { being?; } \\
\text { How has the tengefu influenced well-being?; }\end{array}$ & $\begin{array}{l}\text { What are the hopes and fears you have living here?; } \\
\text { Character of rural landscape: what does emakhaya (the } \\
\text { home landscape or village) mean to you?; } \\
\text { Self and collective identity in the rural village: Who are you } \\
\text { in the village? What is it like to be a young man/young } \\
\text { women/married woman in the village?; } \\
\text { Poster of an issue that you want to use photographs to } \\
\text { depict; }\end{array}$ \\
\hline $\begin{array}{l}\text { Approach to edits, and eliciting } \\
\text { responses }\end{array}$ & $\begin{array}{l}\text { Participants took } 27 \text { photos on single-use } \\
\text { cameras, these were printed as postcard ( } 4 \text { x } 6 \\
\text { inch) prints, and in discussion groups } \\
\text { participants discussed top three photos in detail } \\
\text { while using other images to support discussion }\end{array}$ & $\begin{array}{l}\text { Participants took unlimited photographs and chose } 10-12 \\
\text { photos that they felt best described the theme. These were } \\
\text { printed (postcard size), and given to the photographers } \\
\text { who used these to discuss the theme in groups. If there was } \\
\text { time available afterwards, participants would choose } 3 \\
\text { images from the } 12 \text { to caption in their home language. }\end{array}$ \\
\hline Analysis & Grounded coding of transcribed discussions & Thematic coding of captions and transcribed discussions \\
\hline
\end{tabular}

been printed in 4 × 6 format, focus group discussions were held with resource-user groups (five in one site and four in the other) during which photos were redistributed and discussed. After having time to review all images, participants were asked to select three that best represented how the marine ecosystem contributed to well-being and provide either a verbal or written caption for each image, and share their photos with the group. Discussion continued to how the tengefu affected the relationship between marine ecosystems and human well-being, using other photographs to support the discussion when applicable. Participants were given the hardcopies of their photos at the end of the focus group session.

Focus group sessions were recorded (with permission of participants), transcribed, and translated. Transcripts from the discussions were coded by the second author, and were analyzed alongside nonphotovoice focus group transcripts and interviews. To disseminate results back to the community, the second author compiled a selection of images into posters (one per site) that also included a short, written description on the findings of the study in the local language, at the end of the study. For more details on findings and methodology from the Kenya site, see Mahajan and Daw (2016).

\section{Sense of place, agricultural decline, and rural-urban migration in the Eastern Cape, South Africa}

The former Transkei homeland of South Africa, which falls within the Eastern Cape Province, was designated for traditional smallscale farming, supported by remittance wages from family members who worked in faraway cities. However, the region has witnessed a long-term decline in cultivation and animal husbandry (Andrew and Fox 2004, De Klerk 2007, Shackleton and Luckert 2015) and bush encroachment because of a number of interacting factors (De Klerk 2007, Shackleton et al. 2013). The region remains underdeveloped with high rates of urban migration. Those who remain in the area, are diversifying their livelihoods to include nontimber forest products and marine resources, as well as relying on social welfare grants (Hebinck and Lent 2007, Shackleton and Luckert 2015). In this context, the South Africa case explored rural residents' experiences of and responses to declining subsistence agriculture and continued labor migration to faraway cities, through exploring their sense of place of the rural landscape (Boonstra et al. 2016, Masterson 2016, see also Masterson et al. 2017).

In applying photovoice to this case study, an in-depth process with repeated photovoice exercises was undertaken, with four demographic groups of between three and six individuals, using small "point and shoot" digital cameras (Table 1). Participants were identified based on their interest and willingness to participate as well as belonging to a specific demographic group, divided according to gender and age in alignment with local cultural norms, and were identified based on a snowball sampling method with the assistance of multiple local informants. The groups were divided as follows: young women (21-33 years of age; all mothers but unmarried), young men (22-40 years; unmarried), married older women (36-50 years; all mothers and married), and a second group of men (22-45 years; married and 
unmarried $^{[2]}$. Each group convened multiple times (between four and six times) over five weeks between February and March 2013. At the first meeting of each group, the project was described in isiXhosa and participants were asked if they wanted to participate, and assured that there would be no negative consequences to nonparticipation according to principles of free prior and informed consent. Consent to view and store photographs as well as record conversations was obtained verbally (recorded with permission from each participant). All of the respondents were more comfortable speaking vernacular isiXhosa so discussions were facilitated and translated in vernacular isiXhosa, by our interpreter in real time.

After some training in visual literacy, individuals in the groups engaged in a series of photography exercises along at least two of three themes centered on sense of place of the rural village landscape. These themes (Table 1) emerged from pilot research by the first author and the observation that the isiXhosa word for home landscape (emakhaya) encoded a number of sense of place connections. For each session, the group discussed the theme, and then went out to take photographs of this theme on their own for a few hours. Each participant then selected the 10 to 12 most significant images from the day and these were printed (postcard size prints of $4 \times 6$ inches) and distributed to participants at the next session. Photographers displayed the photos by holding them or lying them on a flat surface and each participant was invited to describe their photographs and what these represented to them personally in a free-form manner to the group. Once they were finished, the group could ask questions. The groups also had the option to create a small and inexpensive communication product from their photographs. All four groups chose to make a poster together, using the photographs they had taken in the previous session. The poster was based on an issue that the group identified, and displayed in public places around the villages. At the last session for each group, each participant was given a digital copy of all of their photographs, and asked for written permission (in their native language) for their photographs to be used in scientific publications and presentations as well as an exhibition. Participants were given the opportunity to remove any photographs that they did not want to be included in the collection, and the authors have also ensured that no photographs of a sensitive nature, e.g., that depict illness, or communityprohibited activities, have been used in publications or presentations. Qualitative analysis focused on the text of photograph captions and transcribed discussions of the photographs. The first author then conducted a thematic analysis of these data, in a manner similar to Braun and Clarke (2006), coding the text for emergent themes related to well-being and sense of place at emakhaya.

In 2015, photos and captions from both case studies were curated in an exhibition to tell the stories of local experiences of socialecological change, and to make visible the human-nature connections and local narratives at the heart of SESs in transition. This exhibition was launched at the Programme for Ecosystem Change and Society Conference (PECS) in Stellenbosch, South Africa in November 2015, for an audience of academics and practitioners in the field of sustainability science.

\section{RESULTS}

\section{Photovoice for understanding human well-being and nuanced social-ecological dynamics}

Results from both cases showed how photovoice can contribute to a more holistic understanding of well-being in the relationship to dynamic ecosystems. As applied to these cases, photovoice exercises produced insights addressing key gaps in the well-being literature (Daw et al. 2011, Chan et al. 2016, Cruz-Garcia et al. 2017), specifically eliciting stakeholder knowledge by highlighting on tangible and intangible connections to nature (subcategories of the connections domain of well-being in Breslow and colleagues' 2016 conceptual framework), disaggregating experiences of human-nature relationships and ecosystem change, and illuminating the socially sensitive issues such as power dynamics surrounding ecosystem use.

\section{Tangible connections to nature}

In both cases, the photovoice exercises, photos, and narrative data provided an inventory of the ways in which the ecosystem influences human well-being, and the practices through which people influence nature. In Kenya, photographs documented daily practices and activities related to marine resources and provided an observational view of daily life and homes of research participants, contextualizing the focus group data. Photos also showed the simple importance of daily marine resource use in generating income (Fig. 1a) and the cascading impacts that income has on other components of material and subjective wellbeing, such as feelings of financial security and alternative sources of income (Fig. 1b and 1c). Photovoice provided visual context for female fish trading and selling (Fig. 1d), and revealed the continuing use of an illicit and unsustainable fishing practice (unnamed to protect participants) believed by local scientists to be eliminated from the region (Fig. 1a and 1e).

In the South African case, participants produced photographs that depicted a range of ways of living with nature, but photographers' discussions around the themes of the photographs often centered on low economic reliance on the ecosystem for well-being and livelihoods. Photographs and discussions identified a range of benefits from ecosystems such as crops, livestock, firewood, wood for construction, and medicinal plants that were presented by the participants as costsaving elements in their landscape, as well as aspects of village life that people enjoyed (Fig. 2a). The low reliance on agriculture for livelihoods was depicted through photographs of abandoned fields (Fig. 2b), home-gardens in which only small portions were planted, and cattle corrals that no longer house cattle (Fig. 2c). Participants' discussions of photographs also illustrated how practices involved in using and experiencing nature and the implications for well-being are gendered; for example, women take pride in fetching firewood and maintaining a woodpile (Fig. 2d), and young men in taking care of the livestock (Fig. 2e).

\section{Intangible connections to ecosystems}

Photographs and discussions revealed the intangible connections concerning, e.g., sense of place and spirituality that people have to ecosystems, which are often difficult to disaggregate and to capture in research on ecosystem services and human well-being (Satz et al. 2013, Breslow et al. 2016, Chan et al. 2016). In the South African case, Figure $2 \mathrm{f}$ depicts the cattle corral that is used 
Fig. 1. Kenya case study photographs and captions.

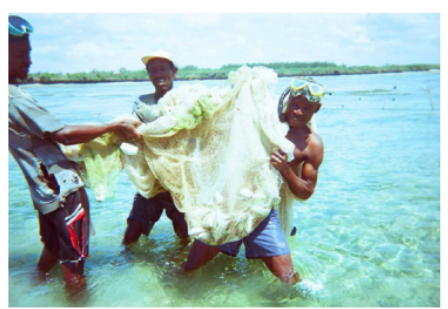

1a @ Participant 2

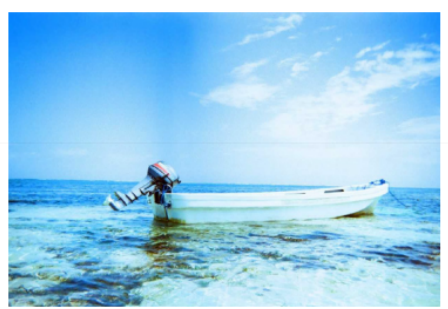

1c ( ) Participant 24

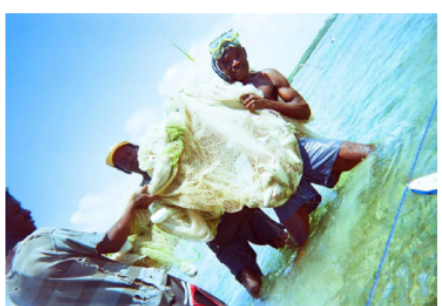

1e (c) Participant 12

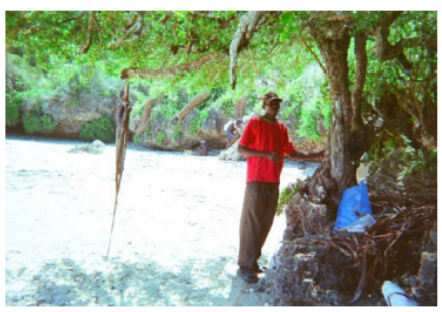

1g $\odot$ Participant 13

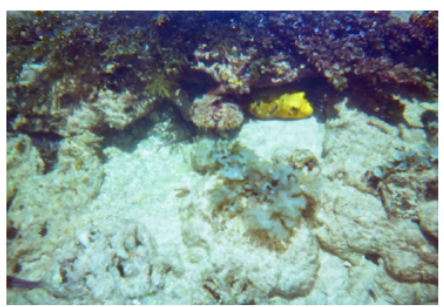

1 i ( ) Participant 9
"This photo I took of fishers who were fishing along the tengefus area. They normally do it in a group of 6-12 people but that depends on the number who turn out on that particular day. This method involves going as a team. The same photo indicates that these fishermen only get good catches when they fish near the tengefu. Fish are found within the tengefu, and once they come out, the fishers trap them, and later sell them to help them earn a living, which helps their families as well."

"It is about the boat. After we had agreed to conserve the area (tengefu) and an evaluation was done, it was seen that the marine area was improving. Then we managed to get aid by AFEW to enable us have a patrolling boat to improve surveillance. The boat has benefited the $B M U$ association by generation of income and payment to the guards, the community in terms of business as they sell fish to traders and some buy for food. I, as an individual, benefit by use of the boat as a means of transportation and for security purpose, and as a tour guide l earn income from tourists."

"This is of fishermen who have managed to get high catches. Very good, but the problem is they have used a net, which destroys corals."

"The standing man in the photo tried to tell me how, in the past, we used to come to this shrine to appease the gods to increase the fish catch. I was trying to tell him that was not the case. It is because of the fishing method we are now using."

"This is a fish (yellow puffer) the tengefus produces... which when sold to the aquarium fetches a lot of money... it is not usually caught but it fetches a lot of money."

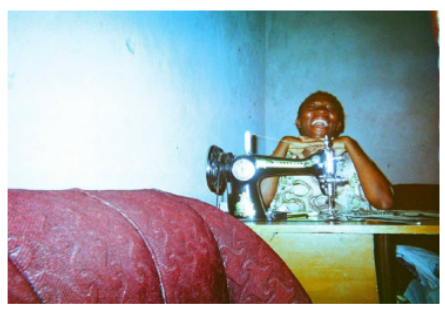

"She is my wife. It is because of the tengefu that I had the chance to complete trainings in first aid and for being a tour guide. That has enabled me to earn some money, enabling me to buy the sewing machine for my wife, and even some household goods. At least I have benefited from the tengefu, for even if I fail to come to the beach (to work) my wife can also contribute to 1b ๔ Participant 23

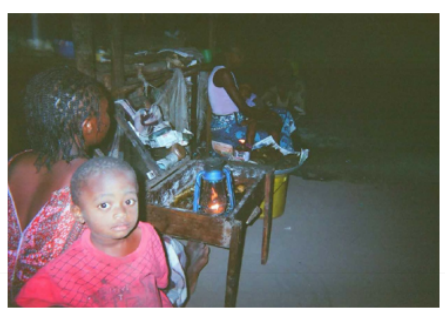

"This is of the women who fry fish. They come to the landing site to buy fish, and back home prepare them to sell to get money, so they can improve their livelihoods." 1d (c) Participant 12

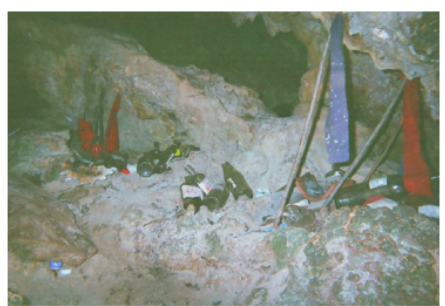

1f @ Participant 9

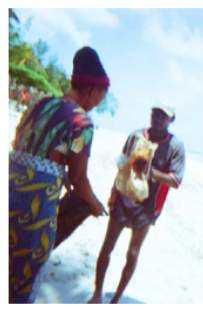

1h (C) Participant 16

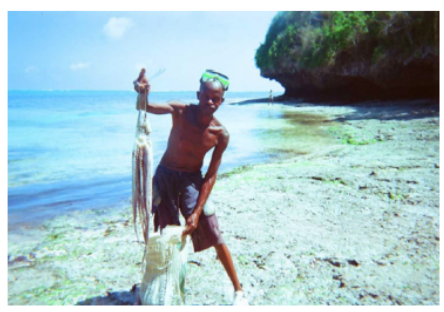

1j ( ) Participant 4
"This is of our swords (shrine) used in cultural practices... people appease their gods to have more catches."
"This is of a spear gun fisher. He has harvested octopus. Even though he not in support of the tengefu... look at the benefits he gets due to us protecting the region!"
Thook this out of sadness. The fishermen were out of the water, and when I lifted the sack to show them I was around, they told me that they were sorry they didn't have any catch, so I did not get anything for that day's sale." 
to keep livestock safe at night, but, as the photographer explains, the cattle corral has even more significance as a sacred site in amaXhosa cultural practice and the spiritual lives of families. The cattle corral is a site where one would address one's ancestors, and is the site of customary rituals. Therefore cattle corrals are still maintained by households who no longer have cattle (Fig. 2c). This illustrates that despite the decline in agriculture and livestock, the cultural importance of an agricultural lifestyle and identity is a strong motivation for residents to continue farming practices as illustrated by this 34-year-old woman:

Culture includes farming. In our culture, we use the things that we farm with [or produce] in some cultural activities. Even maize kernels that are used to prepare a yeast for umnqombothi [traditional beer] - you have to prepare your own, not go and buy.

Photographs also show that the practice of maintaining cattle corrals sustains the resource harvesting and associated knowledge of particular species of trees for branches (Fig. 2a). Similarly, women illustrated the importance of having a woodpile (Fig. 2d), despite the recent electrification of the village, for intangible aspects of well-being. The social expectation for women to tend to a neat woodpile at the homestead maintains the practice of going to collect firewood in the forest, which in turn can either contribute to well-being through a sense of connectedness to nature, or to a sense of fear associated with wilderness (Fig. 2d).

In Kenya, discussion around the photographs revealed that customary cultural ceremonial practices related to marine resource use remained active (Fig. 1f). Prior research had revealed the local beliefs that ritual ceremonies influenced fish harvest (McClanahan et al. 1997), yet other researchers working in the region at the time of data collection believed that these practices no longer existed. Photographs and discussions of a shrine also illustrated diverse perceptions of this ritual practice: some community members believe that appeasing the gods through cultural practices at the shrine increases fish catch (Fig. 1f), while other community members placed their faith in western ecological science and the MPA to improve catch (Fig. 1g). Discussions also showed the importance of fishing for multiple well-being domains, e.g., for contributing to income, and for building community (Fig. 1a).

Perceptions of social-ecological change and impacts on well-being Photographs of resource-use practices or elements of the ecosystem elicited discussions of the patterns of social-ecological change experienced by participants. In the Kenyan case, a female fish trader presented a photo narrative that charted her day-today struggle as a fish trader from inconsistent fish availability (Fig. 1h), a narrative that was shared by many traders evidenced in additional photovoice focus groups and key informant interviews. Discussions around photographs also illustrated how the tengefu had improved fish catch and trading practices for certain individuals (Fig. 1a). Participants discussions of photographs (e.g., Fig. 1i), additionally highlighted the importance of the international aquarium trade as a continued driver for the tengefu, which, although not part of the initial research objectives, pointed to areas for future research.

In the South African case study, photographs and discussions of emakhaya or the rural home area included personal experience of and concern over the decline of farming in the area. Participants expressed their local knowledge of social-ecological processes such as bush encroachment through their photographs and descriptions of esingeni, a local term to refer to abandoned fields where the dense umnga (Acacia karroo) bushes encroach on farmland in the disturbed soil (Fig. 2g). Photographs and captions also presented photographers' holistic local understanding and sense-making of interacting drivers of abandonment and/or decline that include the following: decrease in cattle ownership and consequent loss of draught power to plough fields, loss of jobs and remittance wages to pay for tractors and fences (Fig. 2b), and increased urban migration and the desire to make a living in the city (Fig. 2e). Depictions of unemployed young men and their struggle to plough home-gardens as well as the extensive discussions stimulated by these photographs (see Fig. 2e and $2 \mathrm{~h}$ and captions), also led the researchers to look to broader scale influences on unemployment and labor migration to the cities.

Disaggregated experiences of ecosystem change and perceptions of well-being

The (narrated and written) captions, photographs, and particularly the discussions that these stimulated, showed how actors in both systems perceived environmental change, impacts on their well-being, and aspirations in radically different ways. In Kenya, diverse responses to ecological scarcity were witnessed in how some individuals viewed ecologically destructive fishing practices. Figures 1a and 1e illustrate two different perspectives of the same activity, where one participant recognized the ecological dangers of using a particular fishing method, while another participant used the same image to show the community working together to land a big catch. This dichotomy of views is also echoed by the previously mentioned perceptions of the cultural practices related to shrines and their relationship to ecological outcomes (Figs. 1f and 1g).

Similarly, in South Africa, the young men who took photographs in Figure 2e and $2 \mathrm{~h}$ referred to the difficulty they have in the new democracy where unemployment is high. They describe how they feel stuck in the undeveloped rural areas where declining agriculture means that they have few options for self-actualization and to become responsible Xhosa husbands and land-owners. However, another male participant used the photographs to tell the story of how he had left the poor working conditions of the city and returned to the rural village as a small-holder farmer as well as diversified his livelihood through bee farming and construction (see Fig. 2i), thereby demonstrating different responses to social-ecological changes and impacts on well-being within the community, as well as the motivation and agency behind these responses (described further in Boonstra et al. 2016).

Distribution and access to ecosystem services

In Kenya, discussions of photographs showed power imbalances and conflicts (Fig. 1j) arising from or affecting the success of the tengefu intervention. A key finding from the study was that logistical support from outside actors and financial support from local and international NGOs influenced how each tengef $u$ was perceived. Although discussions in focus groups and interviews reiterated this finding, the photographs provided visual evidence that one tengefu site was more supported by outside actors and NGOs compared to the other, and perceptions were generally more positive in the site that had been more supported. For 
Ecology and Society 23(3): 13

Fig. 2. South Africa case study photographs and captions.

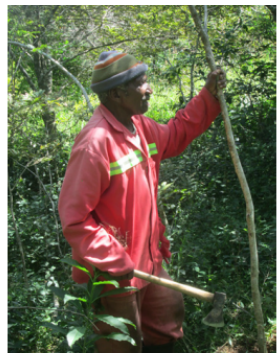

2a $\odot$ Participant 13

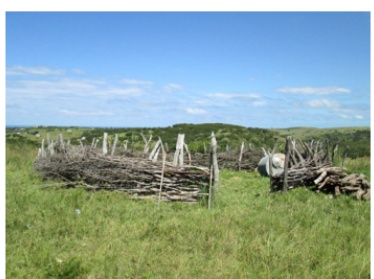

2c ๔ Participant 11

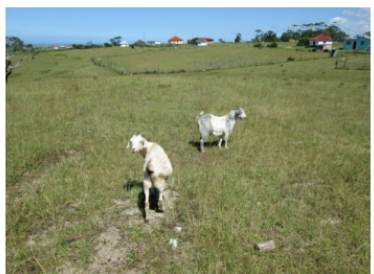

2e $\odot$ Participant 2

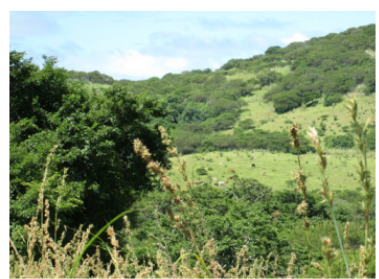

2g ๔ Participant 11

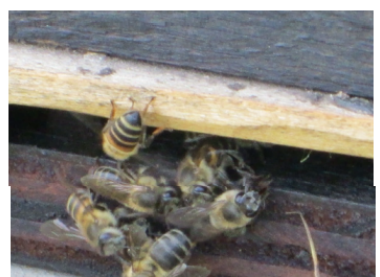

2i ๔ Participant 11
"This grandfather needs poles for his garden - to make it well fenced and strong. I also go out and fetch poles in the forest. The atmosphere there is pleasurable. lenjoy doing that task; it gives me a good chance to smell that lovely scent, and listen to the birds singing while doing the job."

"That is the kraal, but you can see the inside, there's no manure, which clearly shows that they have no livestock there at that home. But even if you haven't got livestock, it's important to have a kraal at home, because that is a place that is needed when you perform your rituals. As people we have different perspectives. Some are in the cities and have jobs and earn much money. Those people see livestock as something unimportant."

"A young man is supposed to plough if he is at home, and produce something from the soil that will help the whole family. [...] These goats clearly show that there is some young man who is taking care of them: they are fit, healthy, fat. As a young man I am responsible for those things. There is garden at my home, and it is planted: lam the one who has done that. It's not what I want to do. I want to rather have some work and provide for the family. [An income] would enable us to have livestock and to be able to plough. But because I'm here amongst the homesteads and not at work [in the city], I am responsible for the garden and goats."

"The open patches are grazing land. But here the bush areas are the 'esingeni'. These areas used to be fields. If you plough that piece of land, and then you don't 'plough it for many years, it becomes ifusi [abondoned fields]. And because it was a piece of land where the soil has been disturbed by ploughing, there acacias will grow and it becomes isinga [land dominated by acacias]."

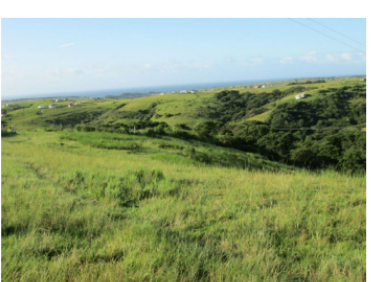

2b ๔ Participant 4

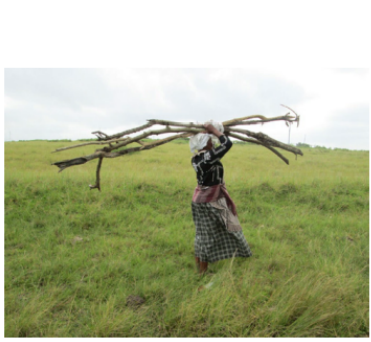

2d @ Participant 08

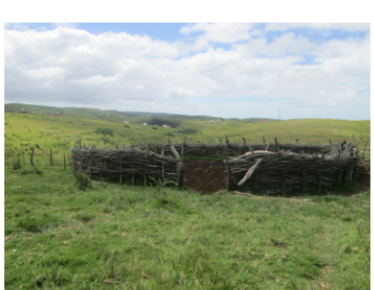

2 f (c) Participant 12

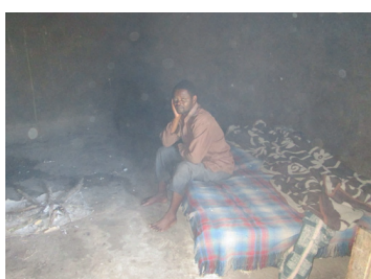

2h ๑ Participant 2
“Emafusi: Abandoned Fields. This photograph represents my anxiety. These fields used to be cultivated. Now they are no longer ploughed. I am afraid that later, people will starve. There are no oxen that were used to plough in days gone by. We haven't got money to hire tractors to plough or plant. That is not good at all. Many homesteads are suffering because they can't plough the soil."

"This is our way of living. You have to go to the forest and come back with a head-bundle of firewood to use at home. That's where women go to get firewood. It's both good and bad to have forests. There in the forest going to collect firewood, as umama, you can meet a rapist hiding there. There are times when you feel happy in the forest - when it's very hot and you enjoy the shade of the trees and you can rest there. But to be alone in the forest is not safe."

"That is the kraal, where you keep your cattle or livestock safe. It's also where you perform your rituals when the time comes for that. This is important to me. If one of my family members is sick or has a problem, we can take that person to the kraal and plea on his behalf to the ancestors, and the problem will be solved."

He is not married because he is not working. To have a wife, the first thing you have to do is to work and have some money, and some cattle to pay a bride price (lobola) for that. He has long been striving to get some work in the city, to no avail. He feels bad that he depends on his mother's pension grant because he is the son who is supposed to look after his mother."

"This is a box that is used as a beehive. It shows that there is some-

thing new here in the amaXhosa culture. It is peculiar to other people. When I first started farming with bees, it raised a lot of questions, even to my father. Where have you heard of such things, in Xhosa culture? But at a later stage my father accepted this. Bees are the type of farming I think I can get profit from. I can sell honey and get money. Bees also play an important role as they help in pollination of plants." 
example, when asked how the tengefu influenced well-being, participants photographed a boat purchased for the community with donor funds (Fig. 1c), and demonstrated how donor investment had influenced other parts of their lives (Fig. 1b).

Differential access to ecosystem benefits among men and women also were shown through photos. In Kenya, a male fish trader photographed a freezer, while female fish traders did not. Prior research in similar fishing communities demonstrated that freezers are an economic asset to traders, allowing fish to be sold, stored, and later sold (Fröcklin et al. 2013). Thus the images reinforced prior findings on gender imbalances in fish trade, highlighting the socioeconomic disadvantages experienced by female fish traders previously documented in the literature (Fröcklin et al. 2013, Yang 2013, Matsue et al. 2014). In South Africa, women who are often marginalized in the patriarchal culture of community affairs used photographs to argue for the legitimacy of their roles and practices in the functioning of the rural village and landscape. For example, one group of women used their photographs and poster to illustrate the importance of traditionally feminine activities such as maintaining the household and garden, as well their participation in the new democracy through voting. The women also used the photographs to reveal the challenges of accessing ecosystem services (participants referred specifically to accessing firewood, and medicinal plants) in transitioning landscapes, especially in terms of feeling unsafe in the encroached and woody areas (Fig. 2d), an issue the men did not raise.

Photovoice helps to mobilize and translate local understandings in knowledge coproduction processes

We illustrated the content through which photovoice as a research tool and process can encourage expression and engagement of marginalized groups, highlighting knowledge, issues, and perspectives that may otherwise be overlooked. Now we turn our attention from content to process and use case material to demonstrate how photovoice, from photographing through to disseminating research results, can mediate mobilization of diverse knowledge and perspectives and translation between different perspectives and ways of knowing (sensu Tengö et al. 2017) and thus facilitate joint learning and understanding between community participants and researchers. To contextualize how photovoice functions in relation to other tools for coproducing knowledge, we also evaluate photovoice against criteria used by Lynam et al. (2007) who reviewed different participatory tools for incorporating local knowledge into decision making (Table 2).

\section{The process of taking photos}

The use of photovoice encouraged open-ended enquiries where participants could take photographs of aspects of daily life and their environmental landscapes. Taking photographs and having open discussion with peers facilitated participants' expression of personal perspectives and motivations, as well as the opportunity to reflect upon these. We observed that the photovoice process that builds in opportunity for reflection, gave participants the time to iteratively develop responses to the research questions. Participants were able to reflect on the benefits from nature in a much more deliberative way through taking photographs, and respond with a significant amount of clarity and depth (supporting the findings of Stedman et al. 2014). Additionally, participants selecting photographs and refining captions through discussion facilitated part of the analysis of the photovoice data, representing a collaboration in coproduction of insights.

Within the scope of these research studies, participants had the space to voice issues that affected them through the photographs and build common understanding through group discussions. In the Kenyan case, participants took photographs to highlight issues about which they felt strongly such as the day-to-day struggles of fishing and trading as a profession. Multiple participants used the photographs to illustrate their concern about land-grabbing, a phenomenon that supplementary data showed affects many small-scale fishers along the coast.

... This used to be our landing site where we used to sell
our catches but currently [has been] grabbed. The
landing site affects our life as without it, we cannot sell
our catches easily or as needed ... as fishermen should
have a landing site, to sell catches at.

In the South African case, groups built trust by sharing their photographic work through repeated meetings. This facilitated group-led creation of posters to voice the perspectives that they felt were not being heard by the broader community. For example, a group of young men used their photographs to create a poster illustrating the entrepreneurial potential of small-scale agriculture, as a counter message to the popular narrative that young people are apathetic, and not interested in agriculture. Through the poster, the group of young men through negotiations and discussions together created text for the poster to go with their photographs to appeal to other community members to revive farming practices. One section of the poster described the young men's purpose in creating this poster in their own words (translated from isiXhosa):

\begin{abstract}
We want to convey this message to people old and young who also love farming and are interested in it. Ploughing is important. We can live on it, especially if we farm with the aim of selling our produce. We also sell livestock. We can form cooperatives that will draw the government's attention, and they will assist us.
\end{abstract}

Photographing and discussing issues important to communities carries ethical risks too, which we present in Table 3. The use of photographs also allowed for the expression and mobilization of local knowledge systems and worldviews. The simplicity of photographing daily lives (Kenyan case), or the rural village and home (South African case) allowed the researchers to overcome the artificial separation of social and ecological inherent in many research concepts, e.g., social-ecological systems, and facilitated the photographers' communication of holistic impressions of ecosystems and well-being that are better aligned with local knowledge systems . Social-ecological linkages, where "social" and "ecological" factors are difficult to distinguish from one another, were captured by photographs of the cattle corral (Fig. 2f) or the woodpile (Fig. 2d) and the customary shrine (Fig. 1f). These features are carriers of knowledge related to management of natural resources as part of an interlinked social-ecological system (cf., e.g., Tengö et al. 2007, Sheil et al. 2015). The images and the discussions they enable can elicit knowledge that otherwise is in the tacit domain or not reflected upon. 
Table 2. Evaluation of photovoice according to Lynam et al. (2007) criteria for participatory tools. Numbers in the fourth column refer to the different images in Figure 1 and 2 as examples.

\begin{tabular}{|c|c|c|c|}
\hline \multirow[t]{7}{*}{ Photovoice Use } & $\begin{array}{l}\text { Does it identify stakeholders or their } \\
\text { relative importance? }\end{array}$ & No & $\begin{array}{l}\text { Emphasis in data collection is on exploring areas of interest to } \\
\text { participants and researchers, not identifying stakeholders. }\end{array}$ \\
\hline & Does it elicit knowledge? & Yes & $\begin{array}{l}\text { Elicited knowledge of short- and long-term social and ecological } \\
\text { processes (Figs. 1g, 2g). }\end{array}$ \\
\hline & Does it elicit values ${ }^{\dagger}$ ? & Yes & $\begin{array}{l}\text { Elicited personal values around ecosystem use (1e) and to nature and } \\
\text { community }(2 \mathrm{~b}) \text {. }\end{array}$ \\
\hline & Is it flexible or narrow in use? & Flexible & $\begin{array}{l}\text { Used as a deep learning tool in South Africa and a scoping tool in } \\
\text { Kenya with variable participant numbers, length of exercises, and total } \\
\text { length of engagement with participants (Table 1). }\end{array}$ \\
\hline & $\begin{array}{l}\text { Does it help deal with culturally } \\
\text { sensitive issues? }\end{array}$ & Yes & $\begin{array}{l}\text { Representational nature of photograph allows participants to choose } \\
\text { how they use photos: either to tell a personal story or allowing them to } \\
\text { distance themselves from sensitive issues by taking a photograph of a } \\
\text { peer }(2 \mathrm{~h}) \text {. }\end{array}$ \\
\hline & What formats does it produce? & & $\begin{array}{l}\text { Photographs with qualitative narratives (captions and focus group } \\
\text { transcripts). }\end{array}$ \\
\hline & Is it analytic or creative? & Creative & $\begin{array}{l}\text { The process of taking photographs stimulates creative thinking. } \\
\text { Additionally, time spent taking photographs gives participants time to } \\
\text { formulate insights and allowed participants to craft narratives and } \\
\text { stories }(1 \mathrm{~g}, 2 \mathrm{~d}) \text {. }\end{array}$ \\
\hline \multirow[t]{9}{*}{$\begin{array}{l}\text { Photovoice } \\
\text { products }\end{array}$} & $\begin{array}{l}\text { Does it encourage communication and } \\
\text { learning among different stakeholders? }\end{array}$ & Yes & $\begin{array}{l}\text { Photographs served as boundary objects in focus group discussions } \\
\text { with participants and in research dissemination, allowing for collective } \\
\text { reflection on contrasting perceptions (varied perceptions between la } \\
\text { and le) or broad topics under inquiry. }\end{array}$ \\
\hline & $\begin{array}{l}\text { Does it encourage colearning or single } \\
\text { group learning? }\end{array}$ & Colearning & $\begin{array}{l}\text { Either depending on context and facilitation approach: Focus group } \\
\text { discussion around photos encourages collective reflection on issues that } \\
\text { affect the community. }\end{array}$ \\
\hline & Is it simple to use? & Yes & $\begin{array}{l}\text { Many people are familiar with photographs in media and, e.g., on } \\
\text { mobile phones. Training sessions with communities revealed that the } \\
\text { cameras were easy to use after just brief training session. }\end{array}$ \\
\hline & $\begin{array}{l}\text { Is it readily translatable across } \\
\text { socioeconomic groups? }\end{array}$ & Yes & $\begin{array}{l}\text { In Kenya and South Africa, photovoice was used in impoverished } \\
\text { communities with low levels of literacy. The process is flexible (see } \\
\text { above); assuming basic photography training is possible, method can be } \\
\text { transferred to different contexts. }\end{array}$ \\
\hline & $\begin{array}{l}\text { Does it allow for dynamic, iterative, or } \\
\text { recursive use? }\end{array}$ & Yes & $\begin{array}{l}\text { In South Africa, the photovoice process was iterative, with several } \\
\text { sessions during which participants took new photographs on different } \\
\text { but related themes, over a number of weeks. }\end{array}$ \\
\hline & $\begin{array}{l}\text { Does it easily provide specialized } \\
\text { knowledge? }\end{array}$ & Yes & $\begin{array}{l}\text { In Kenya, specialized knowledge on fish availability (1i) and gear type } \\
\text { (e.g., 1e) were shared; in South Africa, on the way of life and cultural } \\
\text { practices from different groups in the community with specialized } \\
\text { knowledge of conditions (e.g., } 2 \text { g). }\end{array}$ \\
\hline & $\begin{array}{l}\text { What specific skills are required from } \\
\text { user? }\end{array}$ & $\begin{array}{l}\text { Basic photography } \\
\text { skills }\end{array}$ & $\begin{array}{l}\text { Training sessions with communities revealed that the cameras were } \\
\text { relatively intuitive and easy to use. }\end{array}$ \\
\hline & $\begin{array}{l}\text { Can community members use it } \\
\text { themselves? }\end{array}$ & Yes & $\begin{array}{l}\text { Community members can use printed photographs generated during } \\
\text { the case projects for other purposes, and pending access to cameras or } \\
\text { mobile phones with cameras, could apply the method themselves. }\end{array}$ \\
\hline & Is it capable of rapid implementation? & Yes & $\begin{array}{l}\text { In Kenya the photovoice section of data collection took approximately } \\
\text { six weeks, embedded in a three-month data collection period. }\end{array}$ \\
\hline \multirow[t]{5}{*}{$\begin{array}{l}\text { Photovoice } \\
\text { capabilities }\end{array}$} & $\begin{array}{l}\text { Does it enable expression or } \\
\text { understanding of uncertainty? }\end{array}$ & Yes & $\begin{array}{l}\text { Photovoice is inductive and can capture qualitative individual } \\
\text { perceptions, creating space for expressions of uncertainty or } \\
\text { understanding to be articulated as needed. }\end{array}$ \\
\hline & $\begin{array}{l}\text { Are the results readily communicable to } \\
\text { target groups? }\end{array}$ & Yes & $\begin{array}{l}\text { Photographs lend themselves to being used in communication products } \\
\text { such as an exhibition or posters, which in Kenya and South Africa } \\
\text { summarized key findings for communities and issues identified by } \\
\text { participants }\end{array}$ \\
\hline & $\begin{array}{l}\text { Are the results easily aggregated and } \\
\text { summarized? }\end{array}$ & No & $\begin{array}{l}\text { A large volume of photos and narratives is produced that requires, e.g., } \\
\text { thematic qualitative analysis. However, photos and captions selected by } \\
\text { participants have supported communication of findings to key } \\
\text { stakeholders. }\end{array}$ \\
\hline & $\begin{array}{l}\text { Are the results clear and appealing to } \\
\text { distant/central policy/decision makers? }\end{array}$ & Yes & $\begin{array}{l}\text { Photographs with captions communicate knowledge and issues from } \\
\text { the mouths of participants themselves in an accessible and engaging } \\
\text { format. In the two case studies results (posters and publications) were } \\
\text { shared with local partners. }\end{array}$ \\
\hline & $\begin{array}{l}\text { Does it provide reasonable levels of } \\
\text { accuracy? }\end{array}$ & $\begin{array}{l}\text { Yes, of varied } \\
\text { perceptions }\end{array}$ & $\begin{array}{l}\text { Photovoice documented the varied perceptions and experience of } \\
\text { ecosystem change ( } 1 \mathrm{a} \text { and } 1 \mathrm{e} ; 2 \mathrm{c} \text { ). Accuracy is also enhanced by using } \\
\text { the direct quotations of photographers themselves as data. }\end{array}$ \\
\hline
\end{tabular}

${ }^{\dagger}$ For this purpose, values are defined as desirability, usefulness, and importance. 
Table 3. Ethical considerations in using photovoice.

\begin{tabular}{ll}
\hline \hline & Considerations \\
\hline Topic of enquiry & $\begin{array}{l}\text { The social-ecological linkages and practices of resource } \\
\text { use may be contentious, sensitive, or illegal. }\end{array}$
\end{tabular}

Case experience

Photographs were taken of recognizable individuals using illegal fishing gear and illegally harvesting threatened and marine species in Kenya. Research team in Kenya decided not to display these photographs or block out identifying features of individuals in the photographs when sharing results with local stakeholders. In South Africa, photos were taken of recognizable individuals in a vulnerable position (waiting in line at a hospital) and after discussion in group with researchers, participants decided to delete these photographs from the digital collection.

Context of project The social-ecological interventions being researched may be politically contentious. Other interventions in the area may contribute to reluctance to participate or distrust.

Capacity for participatory research

Trade-offs among informed consent, anonymity, and participation In equipping participants to take photographs themselves, research teams may lose control of the
Photovoice exercises require resources from research team (time, cameras, printing of photos) and from participants (time, skill, and responsibility for camera). This may vary by mode of implementation.
In Kenya, community conflicts around the Marine Protected Areas at one site meant that a fish trader participant in the study (identifiable by their use of cameras) was ostracized by the community, with fishers refusing to sell her fish. Once this was detected, photovoice exercises were cancelled. Research fatigue at the second site site meant that fewer cameras were returned than at the other site.

In Kenya, discussion sessions were limited to one meeting given time limitations of participants. In South Africa, there were fewer participants but almost everyone was able to join for a two-hour session each week. Transport costs and refreshments were provided. In South Africa digital cameras were stored by the research team to avoid unnecessary risk and responsibility for participants. In neither case were participants paid for the time.

Research ethics boards often require anonymity, but the Photographers decided whether their photographs and captions copyright of the photographs belong to the participants. could be used and stored by the projects and for which purposes. processes of retaining confidentiality and informed consent for the participants and subjects of photographs.
To recognize the work and copyright of each participant photographer, participants were given the option to choose whether their names (or a pseudonym) would be associated with their images when they are used in reports, websites, dissemination materials. Discretion was used to ensure that photographs that were used to, e.g., portray destructive environmental practices were either anonymized or not included in any communication or academic material produced from the projects.

Effort was made to manage expectations and present the work as a research project, and to focus on the production of knowledge rather than advocacy in this case.
Expectations of participants and limitations of research process
The use of cameras and encouragement of participants to voice important issues, may raise participants' expectations beyond the constraints of a transdisciplinary research project.

\section{Data interpretation and analysis}

The use of printed photographs in discussions provided a tangible and common platform for translating experiences of socialecological change. Using images with familiar scenes and places catalyzed discussions about the complexity of social-ecological processes, where the photos provided a shared point of reference. For example, in the South African case, photos helped to identify and illustrate particular landscape categories in the local language, isiXhosa: participants took photographs of savanna areas termed isinga, which are abandoned fields encroached by Acacia karroo bushes (Fig. 2g). Discussions highlighted the profound meaning attributed to ising $a$ and the regret and anxiety felt that these pieces of land could not be put back into production because of bush encroachment. Also, sharing photographs of home life and family facilitated the building of trust among participants and facilitators.

The use of a visual medium also helped to overcome cultural and social barriers to communication and facilitate the engagement of individuals or groups who might have otherwise not participated. This was the case with women in both case studies.
For young women in the South African case, for whom there are cultural expectations to be modest and who do not get many opportunities to voice their opinions in community life, showing photographs that they had taken themselves gave the participants the confidence to speak in the group. As the photographers, each woman took control of the narrative as the authority on her own lived experience. These women used the photographs to articulate their role in community life by showing their skills in traditionally male activities such as cattle herding and construction. In Kenya, where female fish traders are often excluded from decision making around marine resource use, the use of photovoice provided a forum to document their views and perceptions alongside the typically dominant male traders and fishermen. Additionally, in both cases, many of the research participants were not literate and groups had varied levels of education and using photographs allowed participants to express their opinions and knowledge on a more equal footing with other participants and the research team. Thus, the photos serve as boundary objects that are owned by the community members but serve as a basis for the external actor to probe and ask questions, then a shared understanding can emerge. Such boundary objects are a key tool for translating 
(and negotiating) knowledge across actors of different knowledge systems (Tengö et al. 2017)

Photos can in certain cases be more representational than realistic (Stedman et al. 2014), which gives participants the freedom to make the story personal or to distance themselves from the issues. This allows participants to take ownership of how they themselves are represented through photographs and how their insights are communicated. In the Kenyan case, a female fish trader shared her personal narrative of the day-to-day struggles faced by fish traders resulting from fluctuations in the ecosystem (Fig. 1h). In contrast, one of the South African young men took a photograph of a peer of his in a dark room, lighting his own fire (Fig. 2h). The peer's story, of unemployment, the dependence on parents, and the lens of failure through which he sees his role in agriculture in rural area, was similar to the photographer's, but the first author observed that telling the story through a photograph of someone else, made it easier for the photographer to distance himself from this common experience. In this way, the participants were still able to discuss the meaning of labor migration in the system, and the ways in which young men respond to this poverty trap with the researcher, but without the photographer having to risk embarrassment and with the photographer in control of how much personal information was shared.

\section{Coproduced insights embedded in research outcomes}

Each of these two photovoice processes facilitated the coproduction of materials and insights useful in communication of issues important to participants as well as research results, a vital component of the research process that is often neglected because of lack of resources and incentives (MacKenzie et al. 2015). Each study generated a body of photographs and captions that through different means of presentation by the authors have helped convey both research findings, and how insights were coproduced with communities. The posters generated in both studies helped summarize and communicate key insights locally, and images from the two cases were also compiled into a photographic exhibition titled "Voices in Transition," shown at an international academic conference, with the goal of bringing community voices into international discourses on socialecological change.

Table 2 summarizes the role of photovoice for coproduction of knowledge based on our case studies, using categories from Lynam et al. 2007. The table demonstrates that the photovoice method and process provides a forum for diverse knowledge and values to be heard, discussed, and eventually translated for use at different scales. It also reiterates the flexible nature of the method, which could facilitate its use in different socioeconomic contexts, especially because the process of taking photographs for such a purpose can be easily learned. This also illustrated the limitations of photovoice as a method: although easily implemented, the process requires time and commitment from participants, and the large amount of data produced is not easily aggregated or summarized (Table 2) as with other participatory methods such as participatory system dynamics models (see Lynam et al. 2007).

The use of the photographs has also brought to the fore several other ethical issues in communicating coproduced knowledge and insights to a broader audience. Ethical dilemmas permeated the photovoice process, starting from the topic of enquiry, the context of the projects, the time, skill, and resources required to execute photovoice to its fullest capacity, the potential trade-offs between informed consent, anonymity, and participation, and the expectations of participants and limitations of a research process (see Table 3 for full summary). Although photovoice provided invaluable materials to communicate about challenges in these communities, these ethical issues limit the capacity for photovoice to deliver short-term results related to shifting power dynamics and in certain cases, communicate valuable findings to different audiences.

\section{DISCUSSION}

Drawing on a legacy of visual and participatory methods, in this paper we have provided a simple definition of photovoice for sustainability science, separating the method from photo elicitation. We have demonstrated that photovoice applied in sustainability research can serve as an intuitive, open, and flexible tool. With the two cases presented, we add to the emerging evidence that this method can illustrate the inextricable links between the social and ecological components of a system from the unique, disaggregated perspective of local people (e.g., BerbésBlázquez 2012, Beh et al. 2013, Bennett and Dearden 2013). We argue photovoice can facilitate the expression of complex socialecological connections, effectively mobilizing and translating local ways of knowing through the medium of photographs and discussions in a research context. These findings and our assessment using Lynam's evaluation criteria (Table 2) establishes photovoice as part of the suite of participatory tools for effective coproduction of knowledge (Lynam et al. 2007).

As the concept of human well-being becomes a deeper focus of social-ecological systems research, conservation, and ecosystembased management (Summers et al. 2012, Milner-Gulland et al. 2014, Breslow et al. 2016) the need for tools that can explore implications of ecosystem change on human well-being in disaggregated ways becomes increasingly vital (Daw et al. 2011, Cruz-Garcia et al. 2017). The cases build on work eliciting local knowledge on social-ecological dynamics (Berbés-Blázquez 2012, Bennett and Dearden 2013), by clearly articulating diverse experiences of people with social-ecological changes (Bennett and Dearden 2013). Photovoice was also shown to be useful in assessing the different components of well-being, exploring both material dimensions of well-being, as well as neglected relational aspects (Coulthard et al. 2011, Satterfield et al. 2013, Chan et al. 2016). We have shown how photovoice can be expanded to serve as a holistic exploratory tool, amenable to use in articulating local and indigenous framings of well-being by making hidden cultural and social connections, such as a strong connection to agricultural or fishing lifestyle, visible to the researchers, echoing the assertions of Maclean and Cullen (2009). These cultural and sacred values may provide clues to important potential leverage points for environmental governance (Tengö et al. 2007, Cocks et al. 2012, Plieninger et al. 2015) and contribute to the developing discourse on holistic well-being in relation to the natural environment (Milner-Gulland et al. 2014).

Photovoice also proved to be an effective tool for beginning to tackle and make visible existing power structures in coproduction of knowledge settings among community members and researchers as suggested by Beh et al. (2013). The two cases demonstrate that photovoice can provide a forum for engagement and learning between participants and researchers; whereas 
learning among community participants was not assessed, in both cases topics that were not in the domain of research emerged through discussing photographs, and influenced the research findings and future directions. The cases also demonstrate how photovoice can produce data that show participants' diverse motivations and ways of knowing (e.g., the two opposite responses to agricultural decline of the photographers of Fig. $2 \mathrm{~h}$ and $2 \mathrm{i}$ ), which is critical to understanding responses to change (Leach et al. 2010, Boonstra et al. 2016). By uncovering divergent perspectives, photovoice can unsettle or enrich dominant environmental narratives by revealing the heterogeneity of motivations and variable agency of individuals in communities (as referred to by Boonstra et al. 2016, see also Masterson et al. 2017). Comparison of the participant experiences shown through their photographs and captions also helped to identify potential sensitivities and power imbalances within communities, such as the ways in which women in the South Africa case were prevented from accessing cultural, spiritual, and material benefits from wooded areas because of their concerns for their safety (Fig. 2d). This is a step toward recognizing the role of power and social process in the distribution of benefits from ecosystems with participatory tools (Berbés-Blázquez 2012).

Through these cases, we have also shown how the use of photovoice in social-ecological systems research may facilitate engagement from voices and issues that are often excluded from key discussions and debates on global change. In both cases, participants, some of whom have little influence in community fora because of, e.g., patriarchal cultural norms, used photographs to share their knowledge and values with the broader community, thus facilitating the self-representation and legitimization of issues important to them. Furthermore, community photographers took the opportunity to describe community- and ecosystem-related issues and problems important to them; this illustrates how photovoice could provide an effective way for local people to be involved in codefining or reformulating the research problem (Tengö et al. 2014).

\section{Practical insights}

Through this article, we have also expanded the application of photovoice to include two modes of practical implementation of the method: as a scoping tool and as a deep learning process (Table 1). Each of these two modes was in response to the different practical considerations of each field research context and may be more or less suitable in specific research situations and producing different data. In the Kenya case, research time and resources were limited, thus photovoice served as a scoping tool to explore connections between a conservation intervention and well-being, while taking an inventory of the social-ecological connections present. Photovoice helped to uncover issues that required further inquiry using other types of field data. In contrast, photovoice was used as a deep learning tool in the South African case, with multiple photography exercises that facilitated the iterative exploration and maturation of themes important to the participants. The rich data from photographs and discussions prompted reflection both by the researchers and participants, encouraging iterative learning about the social-ecological system under inquiry. This mode allowed for trust building within groups, facilitating in-depth discussion and reflection on sensitive ideas around well-being and motivations in responding to SES changes. Although participants had more time to develop photography skills including captioning, this required a greater time investment and produced a large dataset with high redundancy.

Beyond these two modes, we see potential for alternative applications of photovoice that can account for varied ethical concerns (raised in Table 3) and practical concerns in future research contexts. Types of camera, number of photographic exercises, and whether photographs are discussed in groups, may all be varied (e.g., see Berbés-Blázquez 2012 for an application of photovoice in modified transect walks). The use of camera phones and other widely used technology would also facilitate alternative applications of photovoice. Photographs may also be taken by many different stakeholders, first discussed on an individual bases and then discussed with the whole group to facilitate learning and highlight divergent perspectives and viewpoints (e.g., Beh et al. 2013).

There is also scope for development in the analysis of data from photovoice processes. Although we used photovoice to elicit qualitative data collected during group discussions, alternative methods of analysis, for example, a quantitative analysis of the prevalence of themes of photos produced by research (Stedman et al. 2004, Beckley et al. 2007, Kong et al. 2015), would expand the utility of the method for SES research. Promisingly, Bennett and Lantz (2014) have also combined participatory photography with mapping, by georeferencing photographs taken of environmental observations and concerns in order to incorporate landscape heterogeneity and facilitate easier comparison with spatial data sources. Another avenue for further analysis of photo elicitation and photovoice photographs lies in Q-method to identify categories and elucidate conflicting visions of sustainable land use, as Milcu et al. (2014) have done for cultural ecosystem services.

\section{Limitations}

There were several methodological limitations in the application of photovoice to social-ecological research. Both larger-scale phenomena and particular social-ecological processes are not easily captured through participatory photography, e.g., the influence of historical agricultural policy changes on bush encroachment on nonvisible regulating services such as carbon sequestration in South Africa. Although the community photographers described local and personal experiences (e.g., experiences of and reasons for field abandonment see Fig. 2g), researchers missed the opportunity to explore how such local phenomena manifest across scales through other methods and secondary data, given that photovoice researchers had limited resources and capacity. Photographs produced through photovoice also represent a snapshot in time, and consequently the descriptions and discussion of the photographs are crucial to placing images within a broader context of changes over time. Therefore, we advocate that photovoice be used in conjunction with other exploratory methods in the SES toolbox to enhance and broaden insights (as was the case in the research presented here). For example, a scoping photovoice exercise may be used to identify and mobilize existing knowledge and social-ecological connections in social-ecological inventories (Schultz et al. 2007) or broader coproduction of knowledge processes (Tengö et al. 2017) such as a resilience assessment (Sellberg et al. 2015). Additionally, we see potential in other exploratory visual methods such as ethnographic filmmaking or time-lapse photography to 
counter the snapshot nature of photography, but may pose challenges in terms of resources and capacity required of participants.

Photovoice was effective in engaging different resource user groups, but we have found it demands significant time and resources from participants and research facilitators. In comparison to other participatory methods (Lynam et al. 2007), photovoice also produces a large body of data that is not easily summarized, nor does it offer much precision, and requires considerable time and effort to analyze, e.g., through qualitative thematic coding. Additionally, we encountered numerous ethical dilemmas including, for example, when photographs were used to show illegal or socially undesirable practices. The use of photovoice exacerbated some existing tensions in one of the communities in Kenya (Table 3), and the process of reflecting upon issues important to photographers in a group may have raised hopes for ways in which these issues could be solved, most of which were beyond the immediate reach of the participants and researcher. We advocate caution in the application of photovoice to SES research processes, and careful consideration of the expectations that facilitating expressions of community concerns may raise.

Although we found photovoice to be an effective way to encourage more active participation in the research process, the capacity of the method to shift power dynamics beyond the research process alone was limited, likely because of the limitations of the scope and resources of the studies. However given our experience with photovoice in two different research contexts, we believe that photovoice can play an important role in transdisciplinary research projects, in providing a constructive means for codefining social-ecological issues to be addressed, a diversity of perspectives and potential solutions, effectively communicating these to researchers and decision makers (as shown by Castleden et al. 2009, Maclean and Woodward 2013, Maclean and The Bana Yarralji Bubu Inc. 2015) and as a basis for further participation in the implementation of solutions (Brandt et al. 2013, Tengö et al. 2014). Additionally, having policy makers, nongovernment actors, researchers, and local communities carry out a photovoice process together may facilitate the sharing of insights and building of trust and relationships, important for resolving natural resource use conflicts as Beh et al. (2013) have shown (see also Table 3).

\section{CONCLUSION}

To avoid the entrenchment of inequalities in knowledge production for poverty alleviation, we need methods that can harness the democratic nature of images. Photovoice offers a flexible method to elicit knowledge and perceptions of socialecological complexity from the worldviews of local resource users, through the inclusion of unseen perspectives within communities. Photovoice offers a vehicle for diverse community expressions in broader transdisciplinary research processes, by providing a platform through which researchers and local people can engage on more equitable terms. Joint discussions based on the photos can facilitate in translating aspects of tacit or culturally specific knowledge across knowledge systems. Our experience showed that photovoice can permeate the entire research process: influencing the preparation for research (through a focus on ethical practice), the data collection, and providing a tool for communicating results back to communities and to research audiences. The photovoice process encouraged deep reflection among researchers on the process of knowledge production and ownership of data, and our hope is that our insights inspire continued reflection on the expectations and ethical obligations that come with participatory photography as this method is further developed for transdisciplinary SES research with strong relevance for policy and practice.

${ }^{[1]}$ Particularly influential to the authors is the set of practices developed by PhotoVoice for facilitating the use of participatory photography to equip marginalized people to represent themselves and their concerns. This set of tools facilitates participants gaining photography skills and the ability and confidence to express aspects of their lives through images (see Blackman 2007).

${ }^{[2]}$ Because of the prevalence of migrant labor, few older men were present in the villages at the time, and of those who were, none volunteered to be part of the photovoice exercises.

Responses to this article can be read online at: http://www.ecologyandsociety.org/issues/responses. php/10259

\section{Acknowledgments:}

The authors would like to thank the participants in the study for their generous hospitality and willingness to cocreate this research. We learned so much from you and your openness in this journey. We also thank Faith Mabusela, Mlungisile Mbili, Jane Atieno Nyanapah, Amini Tengeza, Rodgers Charo, and the staff of Wildlife Conservation Society for field assistance and support. Simon West, Tim Daw, Elin Enfors, and Julie Goodness provided comments that helped to improve the manuscript. Thank you also to Vivi Mellegård, Wijnand Boonstra, Richard Stedman, Marta Berbés-Blázquez for inspiring discussions. Thank you to Winter Wilson for help with manuscript figures. The research was funded by a grant for development research from the Swedish Science Council (VR 2014-3394); and by Stockholm University and the Stockholm Resilience Centre.

\section{LITERATURE CITED}

Adger, W. N., H. Eakin, and A. Winkels. 2009. Nested and teleconnected vulnerabilities to environmental change. Frontiers in Ecology and the Environment 7(3):150-157. http://dx.doi. org/10.1890/070148

Aggarwal, R. 2006. Globalization, local ecosystems, and the rural poor. World Development 34(8):1405-1418. http://dx.doi. org/10.1016/j.worlddev.2005.10.011

Agrawal, A., and C. C. Gibson. 1999. Enchantment and disenchantment: the role of community in natural resource conservation. World Development 27(4):629-649. http://dx.doi. org/10.1016/S0305-750X(98)00161-2

Andrew, M., and R. Fox. 2004. 'Undercultivation' and intensification in the Transkei: a case study of historical changes in the use of arable land in Nompa, Shixini. Development Southern Africa 21(4):687-706. http://dx.doi.org/10.1080/0376835042000288851 
Baldwin, C., and L. Chandler. 2010. "At the water's edge": community voices on climate change. Local Environment 15 (7):637-649. http://dx.doi.org/10.1080/13549839.2010.498810

Balmford, A., and W. Bond. 2005. Trends in the state of nature and their implications for human well-being. Ecology Letters 8 (11):1218-1234. http://dx.doi.org/10.1111/j.1461-0248.2005.00814. $\underline{\mathrm{x}}$

Beckley, T. M., R. C. Stedman, S. M. Wallace, and M. Ambard. 2007. Snapshots of what matters most: using resident-employed photography to articulate attachment to place. Society \& Natural Resources 20(10):913-929. http://dx.doi.org/10.1080/08941920701537007

Beh, A., B. L. Bruyere, and S. Lolosoli. 2013. Legitimizing local perspectives in conservation through community-based research: a photovoice study in Samburu, Kenya. Society \& Natural Resources 26(12):1390-1406. http://dx.doi.org/10.1080/0894192$\underline{0.2013 .805858}$

Beilin, R. 2005. Photo-elicitation and the agricultural landscape: 'seeing' and 'telling' about farming, community and place. Visual Studies 20(1):56-68. http://dx.doi.org/10.1080/14725860500064904

Bennett, N. J., and P. Dearden. 2013. A picture of change: using photovoice to explore social and environmental change in coastal communities on the Andaman Coast of Thailand. Local Environment 18(9):983-1001. http://dx.doi.org/10.1080/1354983$\underline{9.2012 .748733}$

Bennett, T. D., and T. C. Lantz. 2014. Participatory photomapping: a method for documenting, contextualizing, and sharing indigenous observations of environmental conditions. Polar Geography 37(1):28-47. http://dx.doi.org/10.1080/1088937$\underline{X .2013 .873089}$

Berbés-Blázquez, M. 2012. A participatory assessment of ecosystem services and human wellbeing in rural Costa Rica using photo-voice. Environmental Management 49(4):862-875. http:// dx.doi.org/10.1007/s00267-012-9822-9

Biggs, D., R. Biggs, V. Dakos, R. J. Scholes, and M. Schoon. 2011. Are we entering an era of concatenated global crises? Ecology and Society 16(2):27. http://dx.doi.org/10.5751/ES-04079-160227

Blackman, A. 2007. The photovoice manual. PhotoVoice, London, UK.

Boonstra, W. J., E. Björkvik, L. J. Haider, and V. Masterson. 2016. Human responses to social-ecological traps. Sustainability Science 11(6):877-889. http://dx.doi.org/10.1007/s11625-016-0397$\underline{\mathrm{X}}$

Bosak, K. 2008. Nature, conflict and biodiversity conservation in the Nanda Devi Biosphere Reserve. Conservation and Society 6 (3):211-224. http://dx.doi.org/10.4103/0972-4923.49214

Brandt, P., A. Ernst, F. Gralla, C. Luederitz, D. J. Lang, J. Newig, F. Reinert, D. J. Abson, and H. Von Wehrden. 2013. A review of transdisciplinary research in sustainability science. Ecological Economics 92:1-15. http://dx.doi.org/10.1016/j.ecolecon.2013.04.008

Braun, V., and V. Clarke. 2006. Using thematic analysis in psychology. Qualitative Research in Psychology 3(2):77-101. http://dx.doi.org/10.1191/1478088706qp063oa

Breslow, S. J., B. Sojka, R. Barnea, X. Basurto, C. Carothers, S. Charnley, S. Coulthard, N. Dolšak, J. Donatuto, C. García-
Quijano, C. C. Hicks, A. Levine, M. B. Mascia, K. Norman, M. Poe, T. Satterfield, K. St. Martin, and P. S. Levin. 2016. Conceptualizing and operationalizing human wellbeing for ecosystem assessment and management. Environmental Science \& Policy 66:250-259. http://dx.doi.org/10.1016/j.envsci.2016.06.023

Briggs, L. P., R. C. Stedman, and M. E. Krasny. 2014. Photoelicitation methods in studies of children's sense of place. Children, Youth and Environments 24(3):153-172. http://dx.doi. org/10.7721/chilyoutenvi.24.3.0153

Brondizio, E. S., and F.-M. Le Tourneau. 2016. Environmental governance for all. Science 352(6291):1272-1273. http://dx.doi. org/10.1126/science.aaf5122

Carpenter, S. R., H. A. Mooney, J. Agard, D. Capistrano, R. S. Defries, S. Díaz, T. Dietz, A. K. Duraiappah, A. Oteng-Yeboah, H. M. Pereira, C. Perrings, W. V Reid, J. Sarukhan, R. J. Scholes, and A. Whyte. 2009. Science for managing ecosystem services: beyond the millennium ecosystem assessment. Proceedings of the National Academy of Sciences 106(5):1305-1312. http://dx.doi. org/10.1073/pnas.0808772106

Cash, D. W., W. C. Clark, F. Alcock, N. M. Dickson, N. Eckley, D. H. Guston, J. Jager, and R. B. Mitchell. 2003. Knowledge systems for sustainable development. Proceedings of the National Academy of Sciences of the United States of America 100 (14):8086-8091. https://doi.org/10.1073/pnas.1231332100

Castleden, H., T. Garvin, and Huu-ay-aht First Nation. 2008. Modifying photovoice for community-based participatory indigenous research. Social Science \& Medicine 66(6):1393-1405. http://dx.doi.org/10.1016/j.socscimed.2007.11.030

Castleden, H., T. Garvin, and Huu-ay-aht First Nation. 2009. "Hishuk Tsawak" (Everything is one/connected): a Huu-ay-aht worldview for seeing forestry in British Columbia, Canada. Society \& Natural Resources 22(9):789-804. http://dx.doi. org/10.1080/08941920802098198

Catalani, C., and M. Minkler. 2010. Photovoice: a review of the literature in health and public health. Health Education \& Behavior 37(3):424-451. http://dx.doi.org/10.1177/1090198109342084

Chan, K. M. A., P. Balvanera, K. Benessaiah, M. Chapman, S. Díaz, E. Gómez-Baggethun, R. Gould, N. Hannahs, K. Jax, S. Klain, G. W. Luck, B. Martín-López, B. Muraca, B. Norton, K. Ott, U. Pascual, T. Satterfield, M. Tadaki, J. Taggart, and N. Turner. 2016. Opinion: Why protect nature? Rethinking values and the environment. Proceedings of the National Academy of Sciences 113(6):1462-1465. http://dx.doi.org/10.1073/pnas.1525002113

Chan, K. M. A., A. D. Guerry, P. Balvanera, S. Klain, T. Satterfield, X. Basurto, A. Bostrom, R. Chuenpagdee, R. Gould, B. S. Halpern, N. Hannahs, J. Levine, B. Norton, M. Ruckelshaus, R. Russell, J. Tam, and U. Woodside. 2012. Where are cultural and social in ecosystem services? A framework for constructive engagement. BioScience 62(8):744-756. http://dx.doi.org/10.1525/ bio.2012.62.8.7

Cherem, G. J., and B. L. Driver. 1983. Visitor employed photography: a technique to measure common perceptions of natural environments. Journal of Leisure Research 15(1):65-83. http://dx.doi.org/10.1080/00222216.1983.11969541 
Cinner, J. E., T. M. Daw, T. R. McClanahan, N. Muthiga, C. Abunge, S. Hamed, B. Mwaka, A. Rabearisoa, A. Wamukota, E. Fisher, and N. Jiddawi. 2012. Transitions toward co-management: the process of marine resource management devolution in three east African countries. Global Environmental Change 22:651-658. http://dx.doi.org/10.1016/j.gloenvcha.2012.03.002

Clark, W. C., L. van Kerkhoff, L. Lebel, and G. C. Gallopin. 2016. Crafting usable knowledge for sustainable development. Proceedings of the National Academy of Sciences 113 (17):4570-4578. http://dx.doi.org/10.1073/pnas.1601266113

Cocks, M., J. Alexander, L. Mogano, and S. Vetter. 2016. Ways of belonging: meanings of "nature" among Xhosa-speaking township residents in South Africa. Journal of Ethnobiology 36 (4):820-841. http://dx.doi.org/10.2993/0278-0771-36.4.820

Cocks, M. L., T. Dold, and S. Vetter. 2012. 'God is my forest' Xhosa cultural values provide untapped opportunities for conservation. South African Journal of Science 108(5/6):1-8. http://dx.doi.org/10.4102/sajs.v108i5/6.880

Collier, J. Jr 1957. Photography in anthropology: a report on two experiments. American Anthropologist 59:843-859. https://doi. org/10.1525/aa.1957.59.5.02a00100

Cook, K. 2015. Grappling with wicked problems: exploring photovoice as a decolonizing methodology in science education. Cultural Studies of Science Education 10(3):581-592. http://dx. doi.org/10.1007/s11422-014-9613-0

Coulthard, S., D. Johnson, and J. A. McGregor. 2011. Poverty, sustainability and human wellbeing: a social wellbeing approach to the global fisheries crisis. Global Environmental Change 21 (2):453-463. http://dx.doi.org/10.1016/j.gloenvcha.2011.01.003

Cruz-Garcia, G. S., E. Sachet, G. Blundo-Canto, M. Vanegas, and M. Quintero. 2017. To what extent have the links between ecosystem services and human well-being been researched in Africa, Asia, and Latin America? Ecosystem Services 25:201-212. http://dx.doi.org/10.1016/j.ecoser.2017.04.005

Daniel, T. C., A. Muhar, A. Arnberger, O. Aznar, J. W. Boyd, K. M. A. Chan, R. Costanza, T. Elmquist, C. G. Flint, P. H. Gobster, A. Grêt-Regamey, R. Lave, S. Muhar, M. Penker, R. G. Ribe, T. Schauppenlehner, T. Sikor, I. Soloviy, M. Spierenburg, K. Taczanowska, J. Tam, and A. von der Dunk. 2012. Contributions of cultural services to the ecosystem services agenda. Proceedings of the National Academy of Sciences 109(23):8812-8819. http:// dx.doi.org/10.1073/pnas.1114773109

Daw, T., K. Brown, S. Rosendo, and R. Pomeroy. 2011. Applying the ecosystem services concept to poverty alleviation: the need to disaggregate human well-being. Environmental Conservation 38 (4):370-379. http://dx.doi.org/10.1017/S0376892911000506

De Klerk, H. 2007. The mutual embodiment of landscape and livelihoods: an environmental history of Nqabara. Rhodes University, Grahamstown, South Africa.

Folke, C., R. Biggs, A. V. Norström, B. Reyers, and J. Rockström. 2016. Social-ecological resilience and biosphere-based sustainability science. Ecology and Society 21(3):41. http://dx.doi.org/10.5751/ ES-08748-210341

Fröcklin, S., M. de la Torre-Castro, L. Lindström, and N. S. Jiddawi. 2013. Fish traders as key actors in fisheries: gender and adaptive management. Ambio 42(8):951-962. http://dx.doi. org/10.1007/s13280-013-0451-1

Harper, D. 2002. Talking about pictures: a case for photo elicitation. Visual Studies 17(1):13-26. http://dx.doi. org/10.1080/14725860220137345

Harper, D. 2003. Framing photographic ethnography: a case study. Ethnography 4(2):241-266. http://dx.doi.org/10.1177/1466$\underline{1381030042005}$

Hebinck, P., and P. C. Lent. 2007. Livelihoods and landscapes: the people of Guquka and Koloni and their resources. Brill, Leiden, The Netherlands.

Hergenrather, K. C., S. D. Rhodes, C. A. Cowan, G. Bardhoshi, and S. Pula. 2009. Photovoice as community-based participatory research: a qualitative review. American Journal of Health Behavior 33(6):686-698. http://dx.doi.org/10.5993/AJHB.33.6.6

Hulme, D., and M. Murphree. 2001. African wildlife and livelihoods: the promise and performance of community conservation. James Currey, Oxford, UK.

Kong, T. M., K. Kellner, D. E. Austin, Y. Els, and B. J. Orr. 2015. Enhancing participatory evaluation of land management through photo elicitation and photovoice. Society \& Natural Resources 28 (2):212-229. http://dx.doi.org/10.1080/08941920.2014.941448

Kramer, L., P. Schwartz, A. Cheadle, J. E. Borton, M. Wright, C. Chase, and C. Lindley. 2010. Promoting policy and environmental change using photovoice in the Kaiser Permanente Community Health Initiative. Health Promotion Practice 11(3):332-339. http://dx.doi.org/10.1177/1524839909341555

Leach, M., I. Scoones, and A. Stirling. 2010. Dynamic sustainabilities: technology, environment, social justice. Earthscan, London, UK.

Lynam, T., W. de Jong, D. Sheil, T. Kusumanto, and K. Evans. 2007. A review of tools for incorporating community knowledge, preferences, and values into decision making in natural resources management. Ecology and Society 12(1):5. http://dx.doi. org/10.5751/ES-01987-120105

MacKenzie, C. A., J. Christensen, and S. Turner. 2015. Advocating beyond the academy: dilemmas of communicating relevant research results. Qualitative Research 15(1):105-121. http://dx.doi.org/10.1177/1468794113509261

Maclean, K., and L. Cullen. 2009. Research methodologies for the co-production of knowledge for environmental management in Australia. Journal of the Royal Society of New Zealand 39 (4):205-208. http://dx.doi.org/10.1080/03014220909510581

Maclean, K., and The Bana Yarralji Bubu Inc. 2015. Crossing cultural boundaries: integrating indigenous water knowledge into water governance through co-research in the Queensland Wet Tropics, Australia. Geoforum 59:142-152. http://dx.doi. org/10.1016/j.geoforum.2014.12.008

Maclean, K., and E. Woodward. 2013. Photovoice evaluated: an appropriate visual methodology for Aboriginal water resource research. Geographical Research 51(1):94-105. http://dx.doi. org/10.1111/j.1745-5871.2012.00782.x

Mahajan, S. L., and T. Daw. 2016. Perceptions of ecosystem services and benefits to human well-being from community-based 
marine protected areas in Kenya. Marine Policy 74:108-19. http:// dx.doi.org/10.1016/j.marpol.2016.09.005

Masterson, V. A. 2016. Sense of place and culture in the landscape of home: understanding social-ecological dynamics on the Wild Coast, South Africa. Dissertation. Stockholm Resilience Centre, Stockholm University, Sweden.

Masterson, V., M. Tengö, and M. Spierenburg. 2017. Competing place meanings in complex landscapes: a social-ecological approach to unpacking community conservation outcomes on the Wild Coast, South Africa. Society \& Natural Resources 30 (12):1442-1457. http://dx.doi.org/10.1080/08941920.2017.1347975

Matsue, N., T. Daw, and L. Garrett. 2014. Women fish traders on the Kenyan coast: livelihoods, bargaining power, and participation in management. Coastal Management 42 (6):531-554. http://dx.doi.org/10.1080/08920753.2014.964819

McClanahan, T. R., H. Glaesel, J. Rubens, and R. Kiambo. 1997. The effects of traditional fisheries management on fisheries yields and the coral-reef ecosystems of southern Kenya. Environmental Conservation 24(2):105-120. http://dx.doi.org/10.1017/ $\underline{\mathrm{S} 0376892997000179}$

McGregor, J. A. 2007. Researching human wellbeing: from concepts to methodology. Pages 316-350 in I. Gough and J. A. McGregor, editors. Well-being in developing countries. From theory to research. Cambridge University Press, Cambridge, UK.

Milcu, A. I., K. Sherren, J. Hanspach, D. Abson, and J. Fischer. 2014. Navigating conflicting landscape aspirations: application of a photo-based Q-method in Transylvania (Central Romania). Land Use Policy 41:408-422. http://dx.doi.org/10.1016/j. landusepol.2014.06.019

Millennium Ecosystem Assessment. 2005. Ecosystems and human well-being: synthesis. Island Press, Washington, D.C., USA. [online] URL: https://www.millenniumassessment.org/en/Synthesis. $\underline{\mathrm{html}}$

Milner-Gulland, E. J., J. A. Mcgregor, M. Agarwala, G. Atkinson, P. Bevan, T. Clements, T. Daw, K. Homewood, N. Kumpel, J. Lewis, S. Mourato, B. Palmer Fry, M. Redshaw, J. M. Rowcliffe, S. Suon, G. Wallace, H. Washington, and D. Wilkie. 2014. Accounting for the impact of conservation on human well-being. Conservation Biology 28(5):1160-1166. http://dx.doi.org/10.1111/ cobi. 12277

Mistry, J., and A. Berardi. 2016. Bridging indigenous and scientific knowledge. Science 352(6291):1274-1275. http://dx.doi. org/10.1126/science.aaf1160

Pascual, U., J. Phelps, E. Garmendia, K. Brown, E. Corbera, A. Martin, E. Gomez-Baggethun, and R. Muradian. 2014. Social equity matters in payments for ecosystem services. BioScience 64 (11):1027-1036. http://dx.doi.org/10.1093/biosci/biu146

Pink, S. 2003. Interdisciplinary agendas in visual research: resituating visual anthropology. Visual Studies 18(2):179-192. http://dx.doi.org/10.1080/14725860310001632029

Plieninger, T., C. Bieling, N. Fagerholm, A. Byg, T. Hartel, P. Hurley, C. A. López-Santiago, N. Nagabhatla, E. Oteros-Rozas, C. M. Raymond, D. van der Horst, and L. Huntsinger. 2015. The role of cultural ecosystem services in landscape management and planning. Current Opinion in Environmental Sustainability 14:28-33. http://dx.doi.org/10.1016/j.cosust.2015.02.006

Satterfield, T., R. Gregory, S. Klain, M. Roberts, and K. M. Chan. 2013. Culture, intangibles and metrics in environmental management. Journal of Environmental Management 117:103-114. http://dx.doi.org/10.1016/j.jenvman.2012.11.033

Satz, D., R. K. Gould, K. M. A. Chan, A. Guerry, B. Norton, T. Satterfield, B. S. Halpern, J. Levine, U. Woodside, N. Hannahs, X. Basurto, and S. Klain. 2013. The challenges of incorporating cultural ecosystem services into environmental assessment. Ambio 42(6):675-684. http://dx.doi.org/10.1007/s13280-013-0386-6

Schultz, L., C. Folke, and P. Olsson. 2007. Enhancing ecosystem management through social-ecological inventories: lessons from Kristianstads Vattenrike, Sweden. Environmental Conservation 34 (2):140-152. http://dx.doi.org/10.1017/S0376892907003876

Sellberg, M. M., C. Wilkinson, and G. D. Peterson. 2015. Resilience assessment: a useful approach to navigate urban sustainability challenges. Ecology and Society 20(1):43. http://dx. doi.org/10.5751/ES-07258-200143

Shackleton, R., C. Shackleton, S. Shackleton, and J. Gambiza. 2013. Deagrarianisation and forest revegetation in a biodiversity hotspot on the Wild Coast, South Africa. PLOS ONE 8(10): e76939. http://dx.doi.org/10.1371/journal.pone.0076939

Shackleton, S., and M. Luckert. 2015. Changing livelihoods and landscapes in the rural eastern Cape, South Africa: past influences and future trajectories. Land 4(4):1060-1089. http://dx.doi. org/10.3390/land4041060

Sheil, D., M. Boissière, and G. Beaudoin. 2015. Unseen sentinels: local monitoring and control in conservation's blind spots. Ecology and Society 20(2):39. http://dx.doi.org/10.5751/ ES-07625-200239

Sherren, K., J. Fischer, and I. Fazey. 2012. Managing the grazing landscape: insights for agricultural adaptation from a middrought photo-elicitation study in the Australian sheep-wheat belt. Agricultural Systems 106(1):72-83. http://dx.doi.org/10.1016/ j.agsy.2011.11.001

Stedman, R. C., B. L. Amsden, T. Beckley, and K. G. Tidball. 2014. Photo-based methods for understanding place meanings as foundations of attachment. Page 112-124 in L. C. Manzo and P. Devine-Wright, editors. Place attachment: advances in theory, methods and applications. Routledge, New York, New York, USA.

Stedman, R. C., T. Beckley, S. Wallace, and M. Ambard. 2004. A picture and 1000 words: using resident-employed photography to understand attachment to high amenity places. Journal of Leisure Research 36(4):580-606. http://dx.doi.org/10.1080/00222216.2004.11950037

Steelman, T., E. G. Nichols, A. James, L. Bradford, L. Ebersöhn, V. Scherman, F. Omidire, D. N. Bunn, W. Twine, and M. R. McHale. 2015. Practicing the science of sustainability: the challenges of transdisciplinarity in a developing world context. Sustainability Science 10(4):581-599. http://dx.doi.org/10.1007/ s11625-015-0334-4 
Summers, J. K., L. M. Smith, J. L. Case, and R. A. Linthurst. 2012. A review of the elements of human well-being with an emphasis on the contribution of ecosystem services. Ambio 41 (4):327-340. http://dx.doi.org/10.1007/s13280-012-0256-7

Tengö, M., E. S. Brondizio, T. Elmqvist, P. Malmer, and M. Spierenburg. 2014. Connecting diverse knowledge systems for enhanced ecosystem governance: the multiple evidence base approach. Ambio 43(5):579-591. http://dx.doi.org/10.1007/ $\underline{\text { s13280-014-0501-3 }}$

Tengö, M., R. Hill, P. Malmer, C. M. Raymond, M. Spierenburg, F. Danielsen, T. Elmqvist, and C. Folke. 2017. Weaving knowledge systems in IPBES, CBD and beyond - lessons learned for sustainability. Current Opinion in Environmental Sustainability 26-27:17-25. http://dx.doi.org/10.1016/j.cosust.2016.12.005

Tengö, M., K. Johansson, F. Rakotondrasoa, J. Lundberg, J.-A. Andriamaherilala, J.-A. Rakotoarisoa, and T. Elmqvist. 2007. Taboos and forest governance: informal protection of hot spot dry forest in Southern Madagascar. Ambio 36(8):683-691. http:// dx.doi.org/10.1579/0044-7447(2007)36[683:TAFGIP]2.0.CO;2

Wang, C., and M. A. Burris. 1994. Empowerment through photo novella: portraits of participation. Health Education and Behavior 21(2):171-186. https://doi.org/10.1177/109019819402100204

Wang, C., and M. A. Burris. 1997. Photovoice: concept, methodology, and use for participatory needs assessment. Health Education \& Behaviour 24(3):369-387. http://dx.doi. org/10.1177/109019819702400309

Wang, C. C., W. K. Yi, Z. W. Tao, and K. Carovano. 1998. Photovoice as a participatory health promotion strategy. Health Promotion International 13(1):75-86. http://dx.doi.org/10.1093/ $\underline{\text { heapro/13.1.75 }}$

Yang, A. 2013. The sustainability of trading fish: Evaluating the socioeconomic impacts of illegal beach seines on small-scale fish traders on the coast of Kenya. University of Edinburgh, Edinburgh, UK.

Yang, W., T. Dietz, D. B. Kramer, X. Chen, and J. Liu. 2013. Going beyond the Millennium Ecosystem Assessment: an index system of human well-being. PLoS ONE 8(5):e64582. http://dx.doi. org/10.1371/journal.pone.0064582 